Article

\title{
Truncated Prosequence of Rhizopus oryzae Lipase: Key Factor for Production Improvement and Biocatalyst Stability
}

\author{
Josu López-Fernández, Juan J. Barrero, M. Dolors Benaiges and Francisco Valero *(D) \\ Department of Chemical, Biological and Environmental Engineering, School of Engineering, Universitat \\ Autònoma de Barcelona, 08193 Bellaterra, Barcelona, Spain; josu.lopez@uab.cat (J.L.-F.); \\ JuanJose.Barrero@uab.cat (J.J.B.); mariadolors.Benaiges@uab.cat (M.D.B.) \\ * Correspondence: francisco.valero@uab.cat; Tel.: +34-93-5811809
}

Received: 17 October 2019; Accepted: 12 November 2019; Published: 15 November 2019

\begin{abstract}
Recombinant Rhizopus oryzae lipase (mature sequence, rROL) was modified by adding to its $\mathrm{N}$-terminal 28 additional amino acids from the C-terminal of the prosequence (proROL) to obtain a biocatalyst more suitable for the biodiesel industry. Both enzymes were expressed in Pichia pastoris and compared in terms of production bioprocess parameters, biochemical properties, and stability. Growth kinetics, production, and yields were better for proROL harboring strain than rROL one in batch cultures. When different fed-batch strategies were applied, lipase production and volumetric productivity of proROL-strain were always higher (5.4 and 4.4-fold, respectively) in the best case. rROL and proROL enzymatic activity was dependent on ionic strength and peaked in $200 \mathrm{mM}$ Tris- $\mathrm{HCl}$ buffer. The optimum temperature and $\mathrm{pH}$ for $\mathrm{rROL}$ were influenced by ionic strength, but those for proROL were not. The presence of these amino acids altered lipase substrate specificity and increased proROL stability when different temperature, $\mathrm{pH}$, and methanol/ethanol concentrations were employed. The 28 amino acids were found to be preferably removed by proteases, leading to the transformation of proROL into rROL. Nevertheless, the truncated prosequence enhanced Rhizopus oryzae lipase heterologous production and stability, making it more appropriate as industrial biocatalyst.
\end{abstract}

Keywords: Rhizopus oryzae lipase; P. pastoris; biocatalysis; fed-batch cultures; prosequence; stability

\section{Introduction}

Biodiesel is expected to become a real alternative to fossil fuel due to the depletion of fuel reserves, the better environmental features of biodiesel, and the crucial development of environmental regulations by public administrations [1].

Biodiesel is obtained by transesterification of triacylglycerols with short-chain alcohols, such as methanol and ethanol. The standard industrial procedure is based on alkaline-catalyzed transesterification [2]. However, this method requires a large amount of energy and water for purification. In recent years, lipase-catalyzed transesterification has become an effective alternative owing to its less energy and water consumption and the formation of pure products [3,4].

Lipases (glycerol ester hydrolases, EC. 3.1.1.3) are hydrolytic enzymes that catalyze the hydrolysis of esters in aqueous media. Also, they are widely known for carrying out synthesis, interesterification, and, especially significant for the biodiesel industry, transesterification reactions in organic media [5]. However, two of the most significant restrictions to the industrial use of lipases as biocatalysts in biodiesel production are their costs and their poor stability, notably in the presence of alcohols, such as methanol [6], which limits their reusability and compromises the economic feasibility of the bioprocess. 
Protein engineering is a common target for improving biocatalysts [7]. Some methods, such as directed mutagenesis, have provided promising results in this respect [8]. Others have used some relevant amino acidic sequences, such as prosequences, that can act as intramolecular chaperones to facilitate enzyme folding [9-11]. In addition, immobilization methods have allowed adverse effects on enzyme stability in industrial reactions to be minimized. Such is the case with lipases immobilized onto hydrophobic supports for use as biocatalysts in the production of biodiesel [12]. Lipases covalently linked to chemically modified supports [13] and cross-linked enzyme aggregates [14] have also been explored for biodiesel production. Furthermore, some authors have successfully prevented lipase inactivation by adding alcohol stepwise [15].

Native Rhizopus oryzae lipase (nROL) is a deeply studied enzyme with a wide range of applications, among them, biodiesel synthesis. This lipase is a 1,3-regiospecific enzyme, which is synthesized as a precursor form containing a presequence of 26 amino acids, followed by a prosequence of 97 attached to the $\mathrm{N}$-terminal of a mature sequence of 269 [16]. Both the presequence and the prosequence should be removed when lipase is released. However, nROL still contains 28 amino acids of its prosequence after release. These amino acids have been the subject of much research by virtue of their activity as intramolecular chaperones. Thus, they have been associated with many important effects, such as increased enzyme stability through better folding, decreased synthesis toxicity, and improved intracellular protein transport or even changes in substrate specificity [16-19].

Enzymatic industrial-scale processes feasibility is highly determined by enzyme production, as a significant part of the economic cost of bioprocesses comes from biocatalysts price [3]. ROL has been produced both in the native organism and in various cell factories [20-23]. For instance, the production and function of its prosequence have been examined in Saccharomyces cerevisiae [24-26]. Moreover, Escherichia coli has been used to produce it [27] with improved results by avoiding the formation of inclusion bodies [28]. In any case, Pichia pastoris has proved to be one of the most suitable cell factories for synthesizing ROL [29]. Using this yeast provides a number of advantages, including little endogenous protein secretion, the absence of endogenous lipases and esterases, the presence of a powerful, tightly regulated methanol-inducible alcohol oxidase 1 promoter $\left(\mathrm{P}_{A O X 1}\right)$, and the ability to grow at high cell densities on defined media [30]. The high suitability of P. pastoris for ROL production is confirmed by the vast amount of literature on its cloning and expression [31-35]. Previous studies have examined the effects of cloning and expressing the whole ROL prosequence (97 amino acids) with the mature sequence in P. pastoris [36,37]. The presence of the prosequence was found to alter substrate specificity in the enzyme; the underlying mechanism, however, remains unknown despite some attempts at elucidating the role of the amino acids in the prosequence. Several truncated sequences of the prosequence have been cloned joint to the mature sequence and expressed in Saccharomyces cerevisiae for this purpose [26]. Also, according to some authors working with Aspergillus oryzae, the presence of 28 amino acids of the prosequence alongside the mature sequence is enough for some of the presumed advantages of the prosequence to occur [19].

This work aimed to elucidate whether the truncated prosequence suffices to obtain a biocatalyst with improved industrially relevant features, e.g., enzyme stability and increased heterologous production. Therefore, $28 \mathrm{C}$-terminal amino acids of the prosequence were fused to the $\mathrm{N}$-terminal of recombinant Rhizopus oryzae lipase (rROL) (mature sequence), forming prosequence ROL (proROL), and expressed in Pichia pastoris.

To the best of our knowledge, it is the first time that a joint expression of the truncated prosequence of Rhizopus oryzae lipase and the mature sequence was carried out in Pichia pastoris, performing a study of the heterologous production, enzyme stability, and biochemical features. 


\section{Results and Discussion}

\subsection{Batch and Fed-Batch Production of proROL and $r R O L$}

The proROL producing strain (proROL-strain) used in the tests was selected from a pool of previously screened colonies. A single plasmid integration was confirmed by droplet digital PCR (ddPCR), and a batch culture was run by using a methanol concentration of $10 \mathrm{~g} \mathrm{~L}^{-1}$ for comparison with the rROL producing single-copy strain. All batches were run in duplicate. Initially, all were performed at a controlled $\mathrm{pH}$ of 5.5 (the standard value for rROL producing strain, rROL-strain). However, with proROL-strain, the medium was highly cloudy by the end of the fermentation process (results not shown). This result is likely to be due to the closeness of the $\mathrm{pH}$ to the isoelectric point of proROL—6.08, calculated by bioinformatics tool ExPASy—so the fermentation $\mathrm{pH}$ was reduced to 5 in order to avoid this unwanted effect.

Table 1 compares the main fermentation parameters between proROL-strain and rROL-strain. Although final proROL activity was slightly higher than rROL activity, the greatest difference between the two strains was that in $\mu_{\max }$, which was 1.61 times greater in the former. Apparently, P. pastoris growth was less markedly affected by proROL than by rROL heterologous protein. Also, $Y_{P / X}$ was higher in proROL-strain.

Table 1. Results of the batch with $10 \mathrm{~g}$ methanol $\mathrm{L}^{-1}$.

\begin{tabular}{ccc}
\hline Parameter & rROL & proROL \\
\hline$\mu_{\max }\left(\mathrm{h}^{-1}\right)$ & $0.045 \pm 0.002$ & $0.073 \pm 0.004$ \\
Final activity $\left(\mathrm{AU} \mathrm{mL} \mathrm{mL}^{-1}\right)$ & $10.51 \pm 1.15$ & $12.38 \pm 1.05$ \\
$\Upsilon_{X / S}\left(\mathrm{~g}_{X} \mathrm{~g}_{\mathrm{MeOH}}{ }^{-1}\right)$ & $0.28 \pm 0.02$ & $0.335 \pm 0.005$ \\
$Y_{P / X}\left(\mathrm{AU} \mathrm{gX}^{-1}\right)$ & $3753 \pm 240$ & $5017 \pm 320$ \\
\hline
\end{tabular}

Methanol non-limiting fed-batch (MNLFB) strategy was carried out, maintaining a methanol $(\mathrm{MeOH})$ concentration of $3 \mathrm{~g} \mathrm{~L}^{-1}$ - the optimum level for rROL-strain [38]. Table 2 shows the parameter values obtained for both strains.

Table 2. Results of the fed-batch with rROL and proROL-strains under two methanol addition strategies. Methanol limiting fed-batch (MLFB) under two pre-fixed specific growth rates $\left(0.015\right.$ and $\left.0.045 \mathrm{~h}^{-1}\right)$. Methanol non-limiting fed-batch (MNLFB), maintaining a constant methanol concentration at $3 \mathrm{gL}^{-1}$.

\begin{tabular}{|c|c|c|c|c|c|c|}
\hline \multirow[b]{2}{*}{ Parameter } & \multicolumn{4}{|c|}{ MLFB } & \multicolumn{2}{|c|}{ MNLFB } \\
\hline & $\begin{array}{c}\text { proROL } \\
0.015 \mathrm{~h}^{-1}\end{array}$ & $\begin{array}{c}\text { rROL } \\
0.015 \mathrm{~h}^{-1}\end{array}$ & $\begin{array}{c}\text { proROL } \\
0.045 \mathrm{~h}^{-1}\end{array}$ & $\begin{array}{c}\text { rROL } \\
0.045 \mathrm{~h}^{-1}\end{array}$ & $\begin{array}{c}\text { proROL } \\
3 \mathrm{gL}^{-1}\end{array}$ & $\begin{array}{l}\text { rROL } \\
3 \mathrm{gL}^{-1}\end{array}$ \\
\hline Final activity $\left(\mathrm{AU} \mathrm{mL} \mathrm{L}^{-1}\right)$ & 219 & 135 & 147 & 27 & 358 & 280 \\
\hline$Y_{P / X}\left(\right.$ total AU total $\left.g_{X}^{-1}\right)$ & 5264 & 2644 & 1908 & 479 & 4972 & 5282 \\
\hline$\mu\left(\mathrm{h}^{-1}\right)$ & 0.011 & 0.014 & 0.038 & 0.043 & 0.065 & 0.046 \\
\hline$q_{\mathrm{p}}\left(\mathrm{AU} \mathrm{g}_{\mathrm{X}}^{-1} \mathrm{~h}^{-1}\right)$ & 57 & 46 & 68.5 & 18 & 308 & 322 \\
\hline Specific productivity ${ }^{*}\left(\mathrm{AU} \mathrm{g}_{\mathrm{X}}^{-1} \mathrm{~h}^{-1}\right)$ & 49 & 36 & 44 & 11 & 99 & 102 \\
\hline Volumetric productivity ${ }^{*}\left(\mathrm{AU} \mathrm{L}^{-1} \mathrm{~h}^{-1}\right)$ & 2763 & 1857 & 2782 & 623 & 7160 & 5406 \\
\hline
\end{tabular}

As in the batch cultures, in MNLFB, the mean specific growth rate of proROL-strain exceeded that of rROL-strain. The total fermentation time was quite similar for both (about $52 \mathrm{~h}$ ). The volumetric productivity of proROL-strain was 1.3 times higher than those of rROL-strain. However, $\mathrm{Y}_{(P / X)}, q_{\mathrm{p}}$, and specific productivity were quite similar. Interestingly, the specific growth rate of rROL-strain in the batch and fed-batch MNLFB tests was the same, but lower in the fed-batch tests with proROL-strain. These results suggested that the optimum $\mathrm{MeOH}$ set-point for maximal efficiency during MNLFB might differ between rROL-strain and proROL-strain. 
The differences were more appreciated when Methanol limiting fed-bath (MLFB) strategy was employed for comparing both strains. After the transition phase, the rROL production was practically negligible for all the $\mu$ set-point tested, except for the lowest $\mu$ in which a sharp increase of lipolytic activity was observed at the end of the fed-batch culture [38]. When the MLFB strategy was studied with proROL-strain, a different behavior was observed at the lowest $\left(0.015 \mathrm{~h}^{-1}\right)$ and the highest $\left(0.045 \mathrm{~h}^{-1}\right) \mu$ set-points (Figure 1$)$. In fact, even if proROL-strain production parameters were lower in MLFB strategy than in MNLFB one, they were higher for the two $\mu$ set-points tested when compared with rROL-strain - 4.4 times greater in the best case-as can be seen in Figure 1 and Table 2. As it was described for rROL-strain, MLFB cultures at the lowest $\mu$ improved the titer [38].

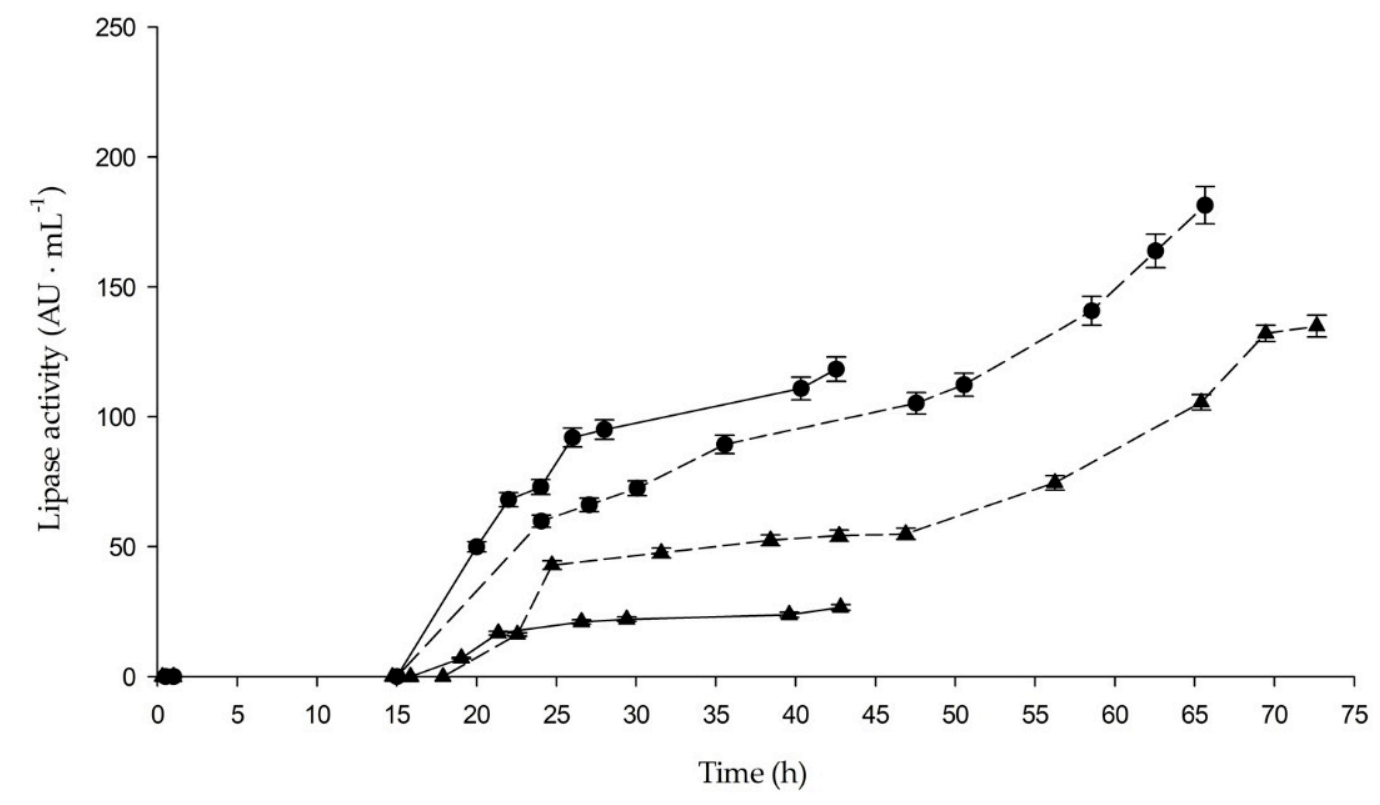

Figure 1. Lipase activity evolution in MLFB (methanol limiting fed-batch) cultures of proROL-strain and rROL-strain at two pre-fixed specific growth rates, 0.015 and $0.045 \mathrm{~h}^{-1}$. pre-fixed $\mu$ of $0.015 \mathrm{~h}^{-1}$ (discontinuous line) and $0.045 \mathrm{~h}^{-1}$ (continuous line). proROL-strain $(\bullet)$ and rROL strain $(\mathbf{\Lambda})$. rROL, recombinant Rhizopus oryzae lipase; proROL, prosequence ROL.

Thus, the better growth of proROL-strain combined with the better productivities observed in both studied strategies, MLFB and MNLFB, suggested a stress reduction during recombinant protein expression caused by the presence of the 28 amino acids of the prosequence. As a result, an unfolded protein response (UPR) phenomena might not be triggered to the same extent as in the rROL-strain [39].

\subsection{Electrophoretic Studies}

The electrophoretic techniques were used to identify differences between proROL and $\mathrm{rROL}$ free enzymes and also to examine some properties of lyophilized powders of each lipase. First, the band corresponding to proROL in the SDS-PAGE gel was identified by using 4-Methylumbelliferone butyrate (MUF)-butyrate as a substrate, and then the molecular weight of the lipase was determined. As can be seen in Figure 2C, the zymogram contained only one active band. This result, which was also obtained with rROL lyophilized powder (Figure 2D), suggested that P. pastoris secretome contained no additional esterases or lipases [40]. After the zymograms were recorded, the gel was dyed with coomassie blue to determine the molecular weight of the enzymes. The band corresponding to proROL fell at $33 \mathrm{kDa}$ (Figure 2B), which is similar to the value reported elsewhere ( $32 \mathrm{kDa}$ ) [36] and also to that for naturally secreted lipase from Rhizopus oryzae [20]. As can also be seen (Figure 2E), the band for $\mathrm{rROL}$ was around $29 \mathrm{kDa}, 4 \mathrm{kDa}$ lower than proROL according to the lack of the 28 amino acids of the prosequence [41]. 
As can be seen in Figure 2F,G, the western blot analysis provided faint bands with similar molecular weights for the two lipases, suggesting that there are different conformations of the lipases. These results are consistent with previously published work, in which some attempts to explain these findings were done, including $\mathrm{N}$-terminal and glycosylation studies [40].

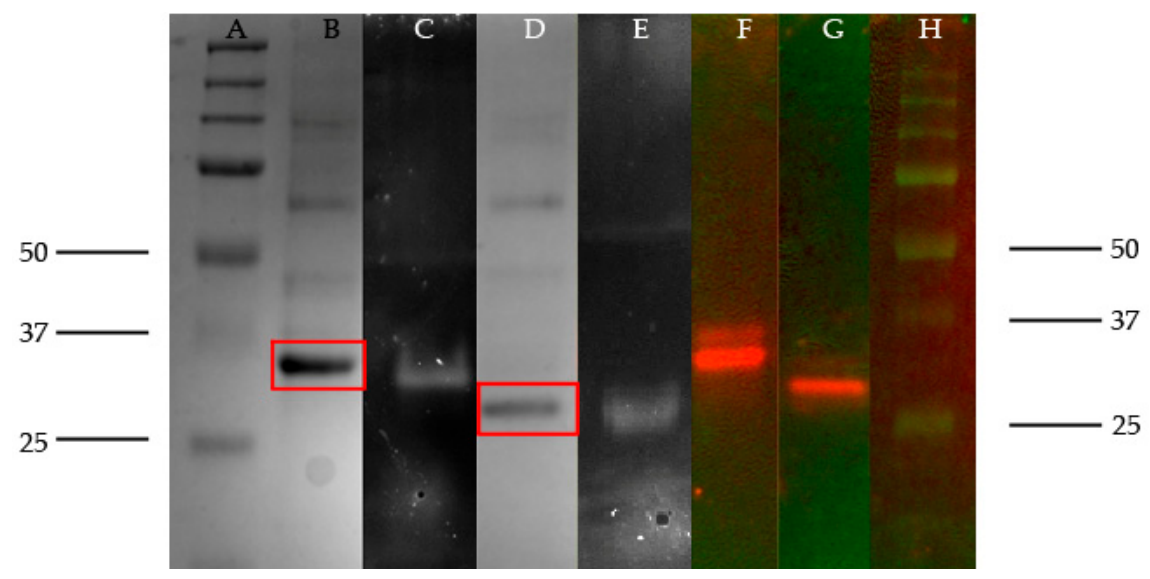

Figure 2. (A) Prestained all blue Precision Plus Protein ${ }^{\mathrm{TM}}$ standards molecular weight marker. (B) SDS-PAGE results for proROL (square). (C) Zymogram for proROL lipase. (D) SDS-PAGE results for rROL lipase (square). (E) Zymogram for rROL lipase. (F) Western blot results for proROL lipase. (G) Western blot results for rROL lipase. (H) Precision Plus ${ }^{\mathrm{TM}}$ all blue standards molecular weight marker.

The western blot results allowed the amount of lipase present in each lyophilized powder to be quantified and the two enzymes to be compared in terms of a specific activity. For this purpose, two samples of purified rROL of known concentration were used as lipase standards (results not shown). As can be seen from Table 3, the presence of 28 additional amino acids in proROL had no adverse effect on the specific activity of the enzyme. The table also shows the protein/lyophilized powder and lipase/total protein ratios. Approximately $25 \%-30 \%$ of all protein in the lyophilized powder was recombinant protein. This result confirmed P. pastoris to be an effective cell factory for heterologous protein production.

Table 3. Specific activity, mass/mass \% of total protein/lyophilized powder, and ratio lipase/protein of proROL and rROL calculated with the Western blot test.

\begin{tabular}{cccc}
\hline Enzyme & $\begin{array}{c}\text { Specific Activity } \\
\text { (AU genzyme }^{-\mathbf{1}} \text { ) }\end{array}$ & $\begin{array}{c}\text { \%Protein/Lyophilized } \\
\text { Powder }\end{array}$ & \% Lipase/Protein \\
\hline rROL & $17.8 \pm 0.6$ & 7.2 & 28.5 \\
proROL & $16.1 \pm 0.3$ & 8.5 & 25.2 \\
\hline
\end{tabular}

Finally, the samples were subjected to densitometry analysis by using SDS-PAGE gels and a protein standard marker (Precision Plus Protein ${ }^{\mathrm{TM}}$ unstained) of known concentration from Bio-Rad (data not shown). The results were similar to those of the western blot test. This suggested that P. pastoris secreted no other proteins similar to the lipases in molecular weight and potentially interfering with densitometric analyses.

\subsection{Influence of Ionic Strength, Temperature, and pH on Enzyme Activity}

proROL was characterized in biochemical terms to examine the influence of ionic strength, temperature, and $\mathrm{pH}$ on enzyme activity, as well as to compare the results with those previously reported for rROL [40]. As shown by reported evidence, ionic strength has a marked effect on enzyme activity. In this work, its influence was examined by using $50-400 \mathrm{mM}$ concentrations of Tris- $\mathrm{HCl}$ buffer 
at $\mathrm{pH}$ 7.25. As expected, lipolytic activity (Figure 3) was strongly influenced by ionic strength because the activity dropped dramatically at $400 \mathrm{mM}$ and $50 \mathrm{mM}$. Both enzymes behaved similarly in this respect, suggesting that the presence of the prosequence had no appreciable effect on this parameter.

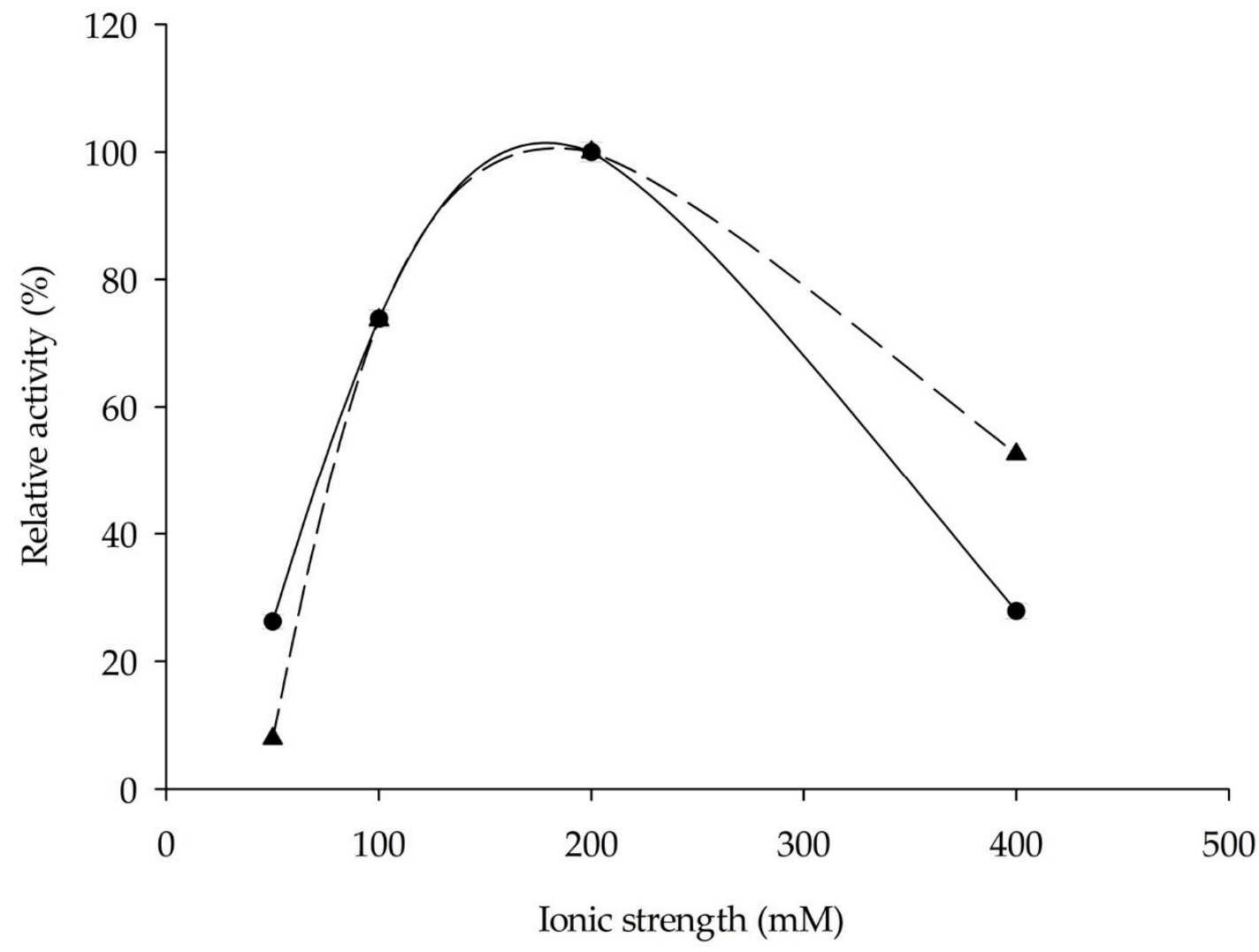

Figure 3. Influence of ionic strength on lipolytic activity relative to the maximum value for proROL and rROL ( $\mathbf{\Delta})$ in Tris- $\mathrm{HCl}$ buffer at $\mathrm{pH} 7.25$ at $30{ }^{\circ} \mathrm{C}$ that was taken to be $100 \%$ in each case.

Due to the significance of the ionic strength in enzyme activity, the temperature and $\mathrm{pH}$ assays were done at $200 \mathrm{mM}$ and $400 \mathrm{mM}$, considering the different behavior observed for rROL [40]. The influence of temperature is illustrated in Figure 4A. As can be seen, the optimum temperature for proROL at both ionic strength levels was $40{ }^{\circ} \mathrm{C}$; by contrast, that for rROL shifted from $40{ }^{\circ} \mathrm{C}$ to $30^{\circ} \mathrm{C}$ at the higher value. Similar optimum temperatures were previously reported (e.g., $40^{\circ} \mathrm{C}$ and $35^{\circ} \mathrm{C}$ for native ROL [20,42], and $30^{\circ} \mathrm{C}$ for lipase formed by the mature sequence produced in P. pastoris [29]). As can be seen from Figure $4 \mathrm{~B}$, the influence of $\mathrm{pH}$ was similar to that of temperature; thus, proROL exhibited an identical optimum $\mathrm{pH}$ at both ionic strength levels, whereas rROL had an optimum $\mathrm{pH}$ of 7.25 at the higher value and eight at the lower. An optimum $\mathrm{pH}$ of eight was previously reported for native ROL [29,42] and one of 7.5 for purified native lipase [20]. 

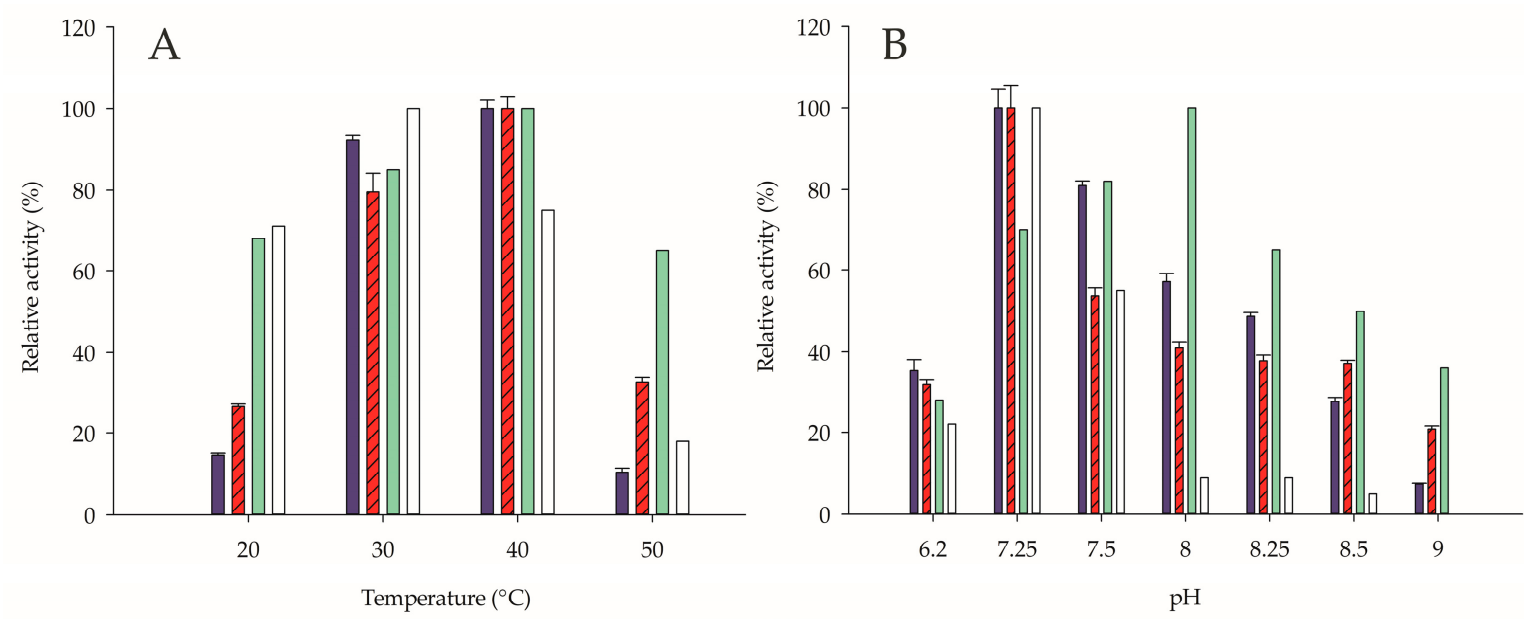

Figure 4. (A) Effect of temperature on lipolytic activity relative to the maximum value for proROL and rROL in Tris-HCl buffer at $\mathrm{pH} 7.25$ at two different ionic strengths (200 and $400 \mathrm{Mm}$ ) that were taken to be $100 \%$ in each case. (B) Effect of $\mathrm{pH}$ on lipolytic activity relative to the maximum value for proROL and rROL in Tris- $\mathrm{HCl}$ buffer at $30{ }^{\circ} \mathrm{C}$ at two different ionic strengths (200 and $400 \mathrm{mM}$ ) that were taken to be $100 \%$ in each case. (dark-blue) $200 \mathrm{mM}$ proROL. (striped-red) $400 \mathrm{mM}$ proROL. (green) $200 \mathrm{mM}$ rROL. (White) $400 \mathrm{mM}$ rROL.

The 28 amino acids in the prosequence have been described as an intramolecular chaperone [18], increasing protein stability. As a result, proROL enzyme activity might be less markedly influenced by changes in temperature or $\mathrm{pH}$.

\subsection{Substrate Specificity}

The presence of the 28 amino acids in the N-terminal of Rhizopus oryzae lipase has been associated with changes in substrate specificity [17]. This led us to examine proROL specificity by using commercial esters of variable carbon chain length and compare the results with those of previous studies on the specificity of rROL and commercial native lipase from R. oryzae (nROL) [40]. As can be seen in Figure 5, the profile for proROL was similar to that for nROL, with a peak at C-8. However, consistent with previous results [25], it was different from that for $\mathrm{rROL}$, which peaked at a greater chain length (C-12). The presence of the 28 amino acids of the prosequence, therefore, had a clear-cut effect on lipase specificity. In fact, previous studies have reported the significance of the 28 amino acids in Rhizopus oryzae lipase substrate specificity by using bioinformatic prediction tools to build 3D models [17]. According to this work, the 28 amino acids of the prosequence are located near to the lid region, and as they contain $50 \%$ of hydrophobic residues, they are supposed to play a relevant role in the interaction with lipidic substrates. 


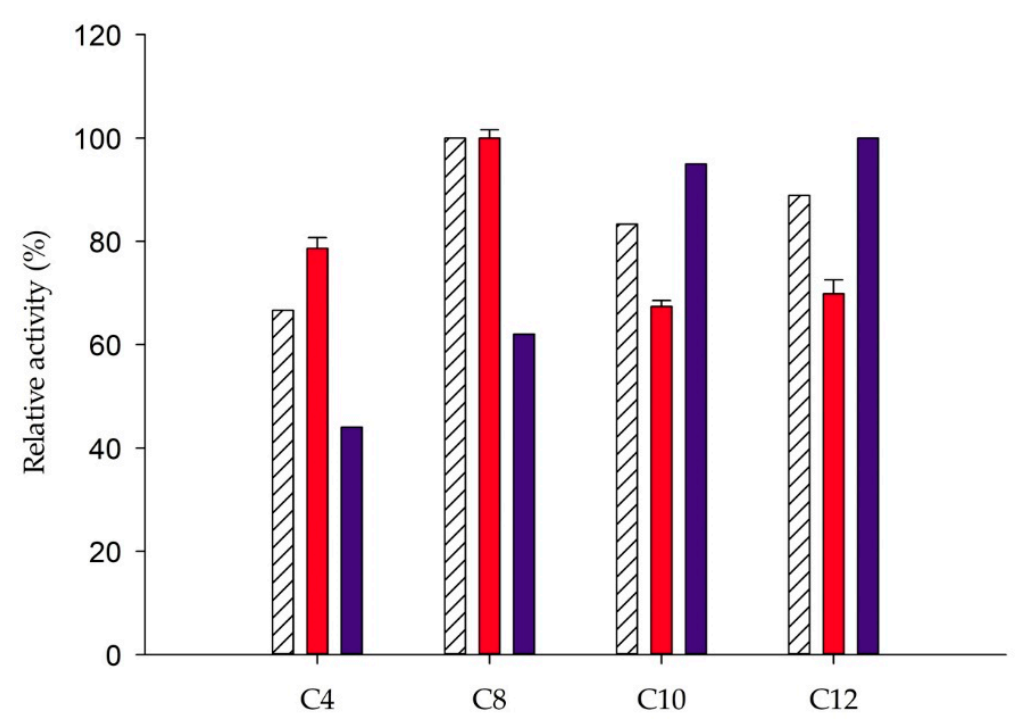

Figure 5. C-4 to C-12 p-nitrophenol ester specificity for nROL (striped-white), proROL (red), and rROL (dark-blue). The maximum activity at $30^{\circ} \mathrm{C}$ in $50 \mathrm{mM}$ phosphate buffer at $\mathrm{pH} 7$ in each run was taken to be $100 \%$.

\section{5. proROL Lipase Proteolysis}

Previous studies confirmed the proteolysis of the N-terminal in purified Rhizopus niveus lipase [41], whose N-terminal is identical with that in R. oryzae lipase [43] - seemingly, proteolysis was the result of the presence of a serine protease in the purified lipase solution. Taking this into account, the proROL enzyme was left in the solution for $24 \mathrm{~h}$ at room temperature to evaluate, by SDS-PAGE, possible proteolysis and compare it with the controls described in Section 3.10. As can be seen from Figure 6, proROL (C2) lost the 28 amino acids of the prosequence. However, no proteolysis was observed in the presence of the protease inhibitor under sterile conditions (C3). Moreover, proteolysis was less marked with $\mathrm{C} 1$ as the likely result of an antiseptic effect of ethanol added to the proROL solution.

Thus, as revealed by the blanks, proteolysis might have been caused by proteases produced by external microbial contaminants present in the lipase solution. In addition, the 28 amino acids were preferentially lost since no other bands suggesting non-specific proteolysis were observed upon lipase hydrolysis. This may have been a result of the 28 amino acids of the prosequence being naturally designed for removal in obtaining lipase, exclusively containing the mature sequence.

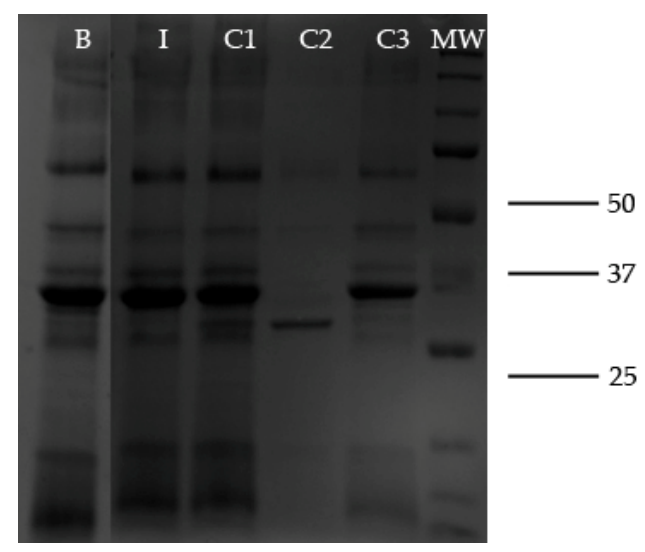

Figure 6. SDS-PAGE analysis of the samples from the proteolysis study. (B) The initial solution of proROL lipase. (I) proROL solution after $24 \mathrm{~h}$ in the presence of inhibitor. (C1) proROL solution after $24 \mathrm{~h}$ in the presence of ethanol. (C2) proROL solution in $5 \mathrm{mM}$ phosphate buffer after $24 \mathrm{~h}$. (C3) Sterilized proROL solution in $5 \mathrm{mM}$ phosphate buffer after $24 \mathrm{~h}$. (MW) Molecular weight marker. 


\subsection{Stability}

Because proROL has been deemed more stable than the enzyme consisting of the mature sequence only [11], proROL stability was compared to rROL stability under three different conditions selected from a previously done experimental design carried out for rROL characterization [5]. Such conditions were chosen on the grounds that they previously led to a variable loss of activity. As can be seen from Figure 7A, proROL was more stable than $\mathrm{rROL}$ after $1 \mathrm{~h}$ of incubation irrespective of the particular $\mathrm{pH}$ and temperature conditions. For example, proROL was up to 7 times more stable than $\mathrm{ROL}$ at $35^{\circ} \mathrm{C}$ and $\mathrm{pH} 8.12$.
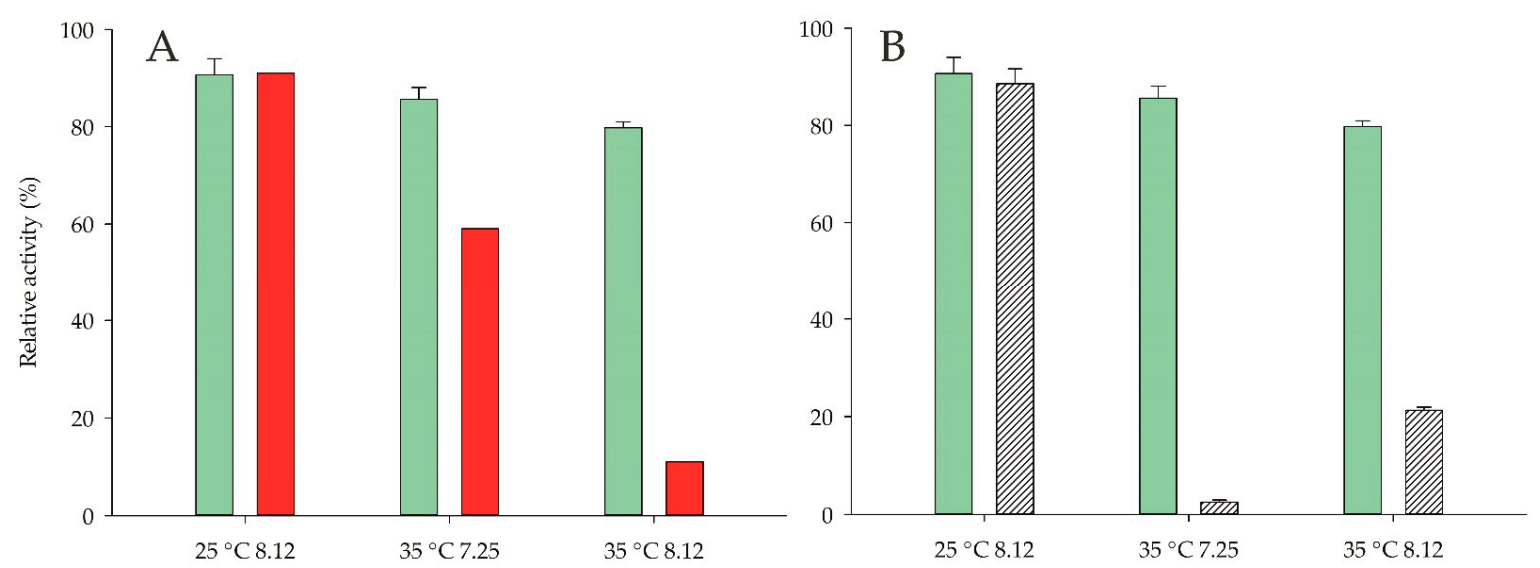

Figure 7. (A) Influence of $\mathrm{pH}$ and temperature on lipase stability. Results obtained after incubation for $1 \mathrm{~h}$ of proROL (black) and rROL (gray) lipase in $200 \mathrm{mM}$ Tris- $\mathrm{HCl}$ buffer under different temperature and $\mathrm{pH}$ conditions. (B) proROL stability after $1 \mathrm{~h}$ (black) and $24 \mathrm{~h}$ (striped-gray) of incubation under different temperature and $\mathrm{pH}$ conditions in $200 \mathrm{mM}$ Tris- $\mathrm{HCl}$ buffer. Activity values relative to $t=0$.

These results led us to examine proROL further than rROL by extending the incubation time to $24 \mathrm{~h}$ under sterile conditions to avoid the unwanted proteolysis described in Section 2.5. As can be seen in Figure 7B, proROL lost only $10 \%$ of its activity after $24 \mathrm{~h}$ of incubation at $25^{\circ} \mathrm{C}$ and $\mathrm{pH} 8.12$. Therefore, the temperature had a stronger effect than $\mathrm{pH}$ on proROL stability, which is consistent with the results of previous studies on rROL stability [5].

The stability of both lipases during $24 \mathrm{~h}$ under sterile conditions in the presence of ethanol or methanol at four different concentrations was also studied. As can be seen from Figure 8, proROL was more stable than rROL irrespective of the conditions. For instance, proROL retained 17 times more activity than $\mathrm{rROL}$ after $24 \mathrm{~h}$ in the presence of $15 \%$ methanol. Also, consistent with previous results [37], both lipases were more strongly affected by ethanol than they were by methanol. However, this result conflicts with those for rROL in biodiesel synthesis reactions, where methanol proved more detrimental [15]. This contradiction can be ascribed to the alcohol interacting with the active site of the enzyme during biodiesel reactions, which is unlikely in a lipase-alcohol solution because the enzyme lid is closed. The influence of the lid on enzyme stability (particularly thermal stability) was previously investigated [44]. 

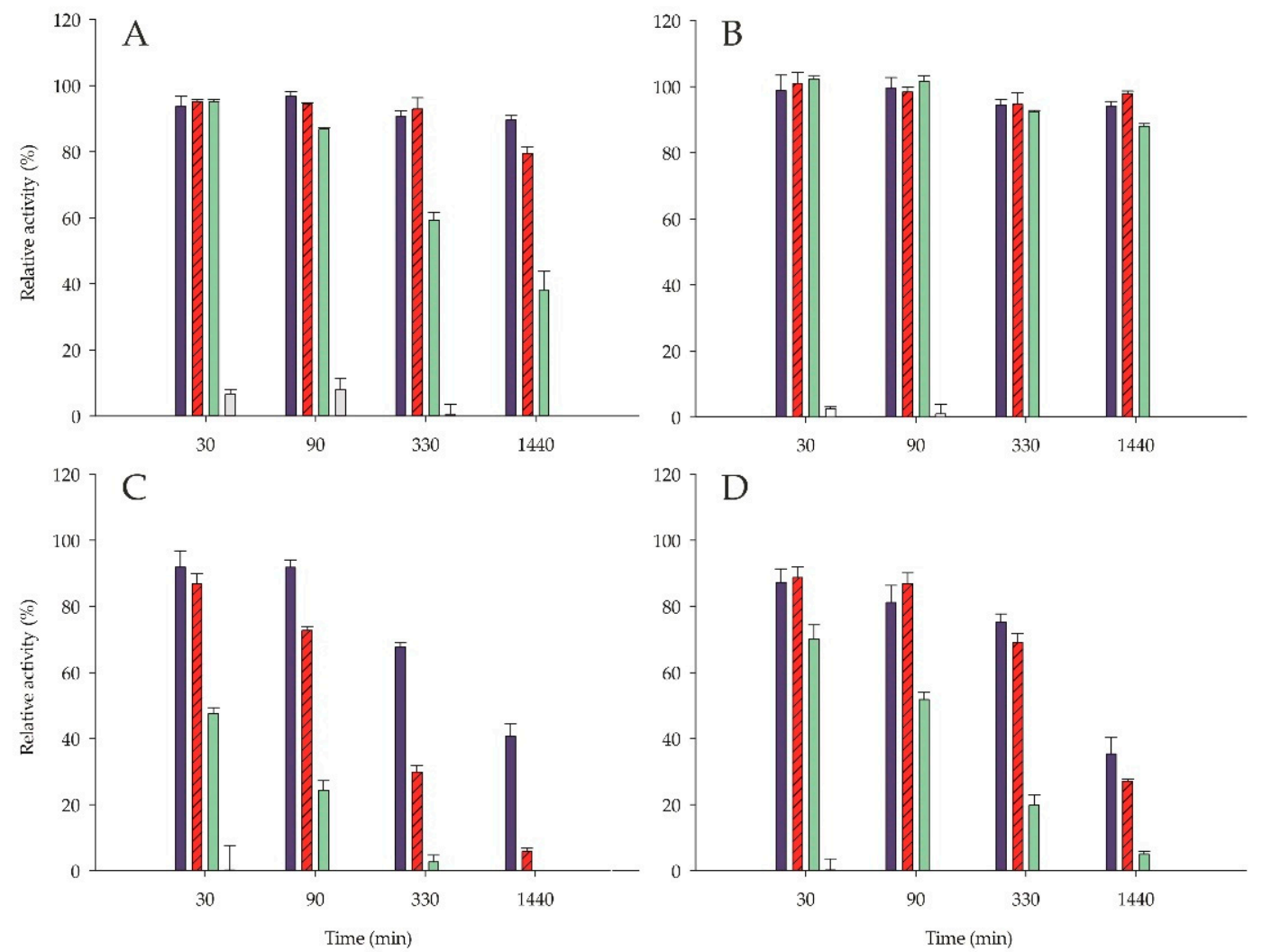

Figure 8. Stability of proROL and rROL in solution in the presence of ethanol and methanol at four different concentrations. (A) proROL in ethanol, (B) proROL in methanol, (C) rROL in ethanol, and (D) rROL in methanol. Activity values relative to $t=0$. Alcohol concentration: $0 \%$ (black), 5\% (striped-white), 15\% (gray), and 30\% (white).

In summary, the 28 amino acids of the prosequence in the N-terminal of lipase improved protein stability not only under different conditions of $\mathrm{pH}$ and temperature but also in the presence of variable concentrations of alcohol.

\section{Materials and Methods}

\subsection{Strains and Derivative Plasmids}

Two different plasmids were used, namely: the pPICZ $\alpha \mathrm{A}$ plasmid containing Rhizopus oryzae lipase (rROL) as expressed by the inducible promoter alcohol oxidase $1\left(\mathrm{P}_{A O X 1}\right)$, which was labeled "rROL plasmid", and a derivative thereof containing the last 28 amino acids of the prosequence in the $\mathrm{N}$-terminal of rROL (proROL). The region corresponding to the 28 amino acids was codon-optimized for P. pastoris (GenScript, Piscataway, NJ, USA) and flanked with XhoI and Bts $\alpha \mathrm{I}$ restriction sites for subsequent digestion-ligation cloning. The rROL plasmid natively contained both restriction sites, so cloning left no unwanted sequences in it. The new plasmid was labeled "proROL plasmid". The Supplementary Information includes the plasmids (Supplementary Materials File S1).

The strain harboring proROL enzyme (proROL-strain) was transformed by electroporing $100 \mathrm{ng}$ of the previously linearized plasmid. This amount limited the number of copies that could be integrated into the genome. The resulting colonies were re-streaked twice in YPD-Zeo plates to avoid population mixing, and 8 colonies were screened, as described elsewhere [45]. This allowed the most representative colony to be selected for further study. The number of single-gene copies was confirmed by digital droplet PCR (ddPCR) with the primers 5 -CCCTG TCGTCCAAGAACAAC-3' and 5'-GAGGACCACCAACAGTGAAG-3' for rROL and proROL, and 
5'-CCTGAGGCTTTGTTCCACCCATCT-3' and 5'-GGAACATAGTAGTACCACCGGACATAACGA-3' for actin [46].

\subsection{Batch Cultures}

The inoculum culture was grown for $24 \mathrm{~h}$ in a $1 \mathrm{~L}$ baffled shake flask at $30^{\circ} \mathrm{C}$ and $150 \mathrm{rpm}$. The flask was filled with $100 \mathrm{~mL}$ YPG medium containing $10 \mathrm{~g} \mathrm{~L}^{-1}$ yeast extract, $20 \mathrm{~g} \mathrm{~L}^{-1}$ peptone, and $20 \mathrm{~g} \mathrm{~L}^{-1}$ glycerol and zeocin to a final concentration $100 \mu \mathrm{g} \mathrm{mL}^{-1}$. Then, a sample with a total optical density $\left(\mathrm{OD}_{600}\right)$ of 20 was centrifuged and resuspended in $100 \mathrm{~mL}$ of sterile water. This was followed by the addition of the inoculum to the bioreactor at $\mathrm{OD}_{600}=2$ and a culture volume of $1 \mathrm{~L}$. Cells were cultivated in a $2 \mathrm{~L}$ bioreactor (Applikon Biotechnology, Delft, The Netherlands).

Invitrogen culture medium [26.7 mL 85\% $\mathrm{H}_{3} \mathrm{PO}_{4}, 0.93 \mathrm{~g} \mathrm{CaSO}_{4}, 18.2 \mathrm{~g} \mathrm{~K}_{2} \mathrm{SO}_{4}, 14.9 \mathrm{~g} \mathrm{MgSO} \cdot 7 \mathrm{H}_{2} \mathrm{O}$,

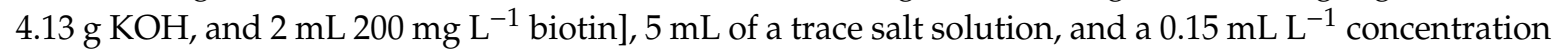
of antifoaming agent (A6426, Sigma-Aldrich Co., St. Louis, MO, USA) were used in $1 \mathrm{~L}$ of culture medium. The trace salt solution contained the following amounts per liter: $6 \mathrm{~g} \mathrm{CuSO} \cdot 5 \mathrm{H}_{2} \mathrm{O}, 0.08 \mathrm{~g}$ $\mathrm{NaI}, 3 \mathrm{~g} \mathrm{MnSO} \cdot \mathrm{H}_{2} \mathrm{O}, 0.2 \mathrm{~g} \mathrm{Na}_{2} \mathrm{MoO}_{4} \cdot 2 \mathrm{H}_{2} \mathrm{O}, 0.02 \mathrm{~g} \mathrm{H}_{3} \mathrm{BO}_{3}, 0.5 \mathrm{~g} \mathrm{CoCl}_{2}, 20 \mathrm{~g} \mathrm{ZnCl}, 65 \mathrm{~g} \mathrm{FeSO}_{4} \cdot 7 \mathrm{H}_{2} \mathrm{O}$, $0.3 \mathrm{~g}$ biotin, and $5 \mathrm{~mL}$ concentrated $\mathrm{H}_{2} \mathrm{SO}_{4}$. The biotin and the trace salt solution were sterilized separately by filtration (SLGV013SL $0.22 \mathrm{~mm}$, Millipore Corporation, Billerica, MA, USA); unlike the original recipe, however, the solutions contained no glycerol but $10 \mathrm{~g}$ methanol $\mathrm{L}^{-1}$ that was added prior to inoculation. Cells were grown at $30^{\circ} \mathrm{C}$ and $\mathrm{pH} 5.5$ with rROL harboring strain (rROL-strain) and 5 with proROL-strain. The oxygen concentration was set at $25 \%$ and controlled by cascade stirring between $500 \mathrm{rpm}$ and $700 \mathrm{rpm}$ with constant aeration at $1 \mathrm{vvm}$.

Samples were withdrawn at different times from the reactor and analyzed for lipolytic activity, biomass, and methanol concentration. The end of each batch run was detected by a sudden increase of dissolved oxygen (DO) concentration in the culture broth.

\subsection{Fed-Batch Cultures}

The inoculum culture was grown for $24 \mathrm{~h}$ in a $1 \mathrm{~L}$ baffled shake flask containing $100 \mathrm{~mL}$ YPG medium and zeocin at $30^{\circ} \mathrm{C}$ and $150 \mathrm{rpm}$. Then, cells were centrifuged and re-suspended in $200 \mathrm{~mL}$ of sterile water. The inoculum was added to the bioreactor at $\mathrm{OD}_{600}=1.5$ and the total culture volume of 2 L. Cells were cultivated in a 5 L Biostat B bioreactor (Sartorius, Guxhagen, Germany), using the same medium as in the batch test.

Initial batch cultivation was done using glycerol as a carbon source with a final concentration of $40 \mathrm{~g} \mathrm{~L}^{-1}$. Once glycerol was depleted, a $5 \mathrm{~h}$ transition stage was started [47]. Finally, a fed-batch stage was performed with methanol as the sole carbon source to facilitate protein induction. Two strategies were followed for methanol addition, limiting fed-batch culture (MLFB) and non-limiting fed-batch culture (MNLFB). Under MLFB strategy, pre-fixed 0.015 and $0.045 \mathrm{~h}^{-1}$ specific growth rates were employed, while for MNLFB, methanol concentration was set at $3 \mathrm{~g} \mathrm{~L}^{-1}$, the previously published optimum concentration for rROL-strain. Methanol concentration was monitored and controlled with a Raven Biotech (Vancouver, BC, Canada) probe immersed in the culture broth. Further information about the fed-batch cultivation set-up, operating conditions, and main cultivation parameters can be found elsewhere $[38,48]$.

\subsection{Lipases}

Fermentation runs were followed by centrifugation, microfiltration, ultrafiltration, and lyophilization of the culture broth to remove biomass and concentrate the enzyme [49].

\subsection{Chemicals}

4-Methylumbelliferone butyrate (MUF-butyrate), $p$-nitrophenol esters, phenylmethylsulfonyl fluoride (PMSF) and culture media reagents, unless otherwise stated, were purchased from Sigma-Aldrich (St. Louis, MO, USA). The lipase colorimetric kit used for the activity assay was 
obtained from Roche (Roche kit 11821792, Mannheim, Germany), and bovine serum albumin standards (Ref. 11811345) were supplied by Thermo Fisher Scientific (Waltham, MA, USA).

\subsection{Electrophoresis}

Sodium dodecyl sulfate-polyacrylamide gel electrophoresis (SDS-PAGE) was carried out as described elsewhere [40]. Prestained all blue and unstained Precision Plus Protein ${ }^{\mathrm{TM}}$ standards from BioRad (Hercules, CA, USA) were used for molecular weight determination and band quantification, respectively. Zymograms were obtained as described elsewhere [50] and followed by staining of the gel to determine the molecular weight of each active protein.

Gel DocTM EZ Imager and ImageLab v.5.2 software from BioRad were used for further image analysis.

Western blot tests were done by SDS-PAGE. Then, proteins were transferred from the gel to a nitrocellulose membrane by using a Trans-Blot Turbo Midi Nitrocellulose Transfer Pack from BioRad (Hercules, CA, USA) [51]. Mouse anti-ROL antiserum obtained from the Servei de Cultius Cel-lulars, Producció d'Anticossos i Citometria (Universitat Autònoma de Barcelona, Bellaterra, Spain) was used for lipase immunorecognition.

Image analysis and quantification were done with a Molecular Imager ${ }^{\circledR}$ ChemiDoc $^{\mathrm{TM}}$ XRS System and the software ImageLab v.5.2. rROL purified samples of known concentration were used for 2-point calibration and sample quantification.

\subsection{Lipolytic Activity}

Lipolytic activity was determined on a Cary Varian 300 spectrophotometer (Varian Australia, Mulgrave, VIC, Australia) using the Roche lipase colorimetric kit at $30^{\circ} \mathrm{C}$ in $200 \mathrm{mM}$ Tris- $\mathrm{HCl}$ buffer at pH 7.25 unless otherwise stated. Measurements were made in triplicate at $580 \mathrm{~nm}$ [52].

\subsection{Total Protein}

Protein concentration was determined by using the Bradford method with bovine serum albumin as standard [53].

\subsection{Substrate Specificity}

Substrate specificity was assessed by monitoring the hydrolysis of C-4 to C-12 $p$-nitrophenol esters with a Cary Varian 300 spectrophotometer at $30^{\circ} \mathrm{C}$ in $50 \mathrm{mM}$ phosphate buffer at $\mathrm{pH} 7$ as described elsewhere [40].

\subsection{Proteolytic Activity Inhibition}

Proteolytic activity inhibition was assessed by using the PMSF inhibitor at a $1.5 \mathrm{mg} \mathrm{mL}^{-1}$ concentration in ethanol mixed with lipase solution in $5 \mathrm{mM}$ phosphate buffer at $\mathrm{pH} 7$ [41]. Blanks containing no PMSF (C1), or neither alcohol nor PMSF (C2), were also used. An additional blank (C3) was prepared by sterilizing a sample of lipase solution by filtration with $0.22 \mu \mathrm{m}$ pore size from Millipore Corporation (Billerica, MA, USA). All samples were kept in a roller at room temperature for $24 \mathrm{~h}$.

\subsection{Enzyme Stability}

Temperature and $\mathrm{pH}$ stability were examined by dissolving lyophilized lipase powder in $200 \mathrm{mM}$ Tris- $\mathrm{HCl}$ buffer under suitable $\mathrm{pH}$ and temperature conditions. Samples were withdrawn for analysis after $1 \mathrm{~h}$ and $24 \mathrm{~h}$.

Alcohol tolerance in the lipases was assessed in $200 \mathrm{mM}$ Tris- $\mathrm{HCl}$ buffer at $\mathrm{pH} 8.2$, containing $0 \%-30 \%(\mathrm{v} / \mathrm{v})$ alcohol. Samples were withdrawn for analysis over the first $24 \mathrm{~h}$. 
Enzymatic activity was determined by the previously described method, diluting the sample not to alter lipolytic activity assay conditions.

Stability studies were done under sterile conditions by previously passing the samples through a filter of $0.2 \mu \mathrm{m}$ pore size to avoid unwanted proteases coming from microbial contaminants.

\section{Conclusions}

Two of the main drawbacks of lipase-catalyzed transesterification for the biodiesel industry are lipase production cost and its stability, which are directly related to the economic feasibility of the whole process. The presence of only 28 amino acids of the prosequence in proROL resulted in significant improvements in comparison to the mature sequence (rROL). In terms of bioprocess engineering, the maximum specific growth rate value for proROL producing strain, $0.073 \mathrm{~h}^{-1}$, was 1.6 times greater than that for rROL-strain but still much smaller than the value for wild-type P. pastoris (about $0.12 \mathrm{~h}^{-1}$ ). In addition, lipase production and volumetric productivity of proROL-strain in fed-batch cultures were also greater in both methanol-addition strategies. All these results suggested a stress reduction caused by recombinant protein expression during proROL production and a potential decrease in the economic cost of the biocatalyst due to higher productivity.

Although proROL and rROL free lipases showed similar specific activity and patterns during biochemical characterization, the presence of the 28 amino acids in the former resulted in some differences. Thus, proROL differed not only in molecular weight but also in the optimum $\mathrm{pH}$ and temperature at each ionic strength. Substrate specificity also differed between the two lipases, and selective proteolysis of the 28 amino acids of the prosequence was observed. However, the most significant difference was the increased stability of proROL relative to rROL under all the stability tests carried out at different $\mathrm{pH}$ and temperature conditions in the presence or absence of alcohols (methanol and ethanol). The advantageous traits of this lipase may open up new avenues for its application in the biodiesel industry.

Supplementary Materials: The following are available online at http://www.mdpi.com/2073-4344/9/11/961/s1, Supplementary Materials File S1 contains "rROL plasmid", which includes the map of the plasmid in. dna format (SnapGene), and "proROL plasmid", which includes the map of the plasmid in. dna format (SnapGene).

Author Contributions: J.L.-F. and J.J.B. performed the experiments, analyzed the data, and wrote the paper. M.D.B. and F.V. supervised the research, wrote, and reviewed the paper.

Funding: This research was funded by MINECO and FEDER under Project CTQ2016-74959-R. The authors' group is member 2017-SGR-1462 and the Reference Network in Biotechnology (XRB) of Generalitat de Catalunya.

Acknowledgments: Josu Lopez-Fernandez acknowledges the award of a scholarship from the Basque Government (PRE_2017_1_0110) and Juan Jose Barrero an FPI scholarship from MINECO (BES-2017-080858).

Conflicts of Interest: The authors declare no conflict of interest.

\section{Abbreviations}

$\begin{array}{ll}\begin{array}{l}\text { ROL } \\ \text { rROL }\end{array} & \begin{array}{l}\text { Rhizopus oryzae lipase } \\ \text { nROL }\end{array} \\ \text { Recombinant Rhizopus oryzae lipase formed by the mature sequence } \\ \text { proROL } & \begin{array}{l}\text { Native Rhizopus oryzae lipase } \\ \text { the N-terminal of the mature sequence. }\end{array} \\ \text { rROL-strain } & \text { Genetically modified Pichia pastoris strain to produce rROL } \\ \text { proROL-strain } & \text { Genetically modified Pichia pastoris strain to produce proROL } \\ \text { MeOH } & \text { Methanol } \\ \text { MNLF } & \text { Methanol non-limiting fed-batch } \\ \text { MLFB } & \text { Methanol limiting fed-batch } \\ \mathrm{Y}_{(\mathrm{P} / \mathrm{X})} & \text { Product-biomass yield }\left(\mathrm{AU} \cdot \mathrm{gX}^{-1}\right) \\ \mathrm{Y}_{(\mathrm{X} / \mathrm{S})} & \text { Biomass-substrate yield }\left(\mathrm{gX} \cdot \mathrm{gS}^{-1}\right) \\ \mu & \text { specific growth rate }\left(\mathrm{h}^{-1}\right)\end{array}$




$\begin{array}{ll}\mu_{\max } & \text { maximum specific growth rate }\left(\mathrm{h}^{-1}\right) \\ \mathrm{q}_{\mathrm{p}} & \text { specific production rate }\left(\mathrm{AU} \cdot \mathrm{gX}^{-1} \cdot \mathrm{h}^{-1}\right) \\ \mathrm{UPR} & \text { Unfolded protein response } \\ \mathrm{P}_{\text {AOX1 }} & \text { Inducible promoter alcohol oxidase 1 }\end{array}$

\section{References}

1. Sandoval, G.; Casas-Godoy, L.; Bonet-Ragel, K.; Rodrigues, J.; Ferreira-Dias, S.; Valero, F. Enzyme-Catalyzed Production of Biodiesel as Alternative to Chemical-Catalyzed Processes: Advantages and Constraints. Curr. Biochem. Eng. 2017, 4, 109-141. [CrossRef]

2. Manaf, I.S.A.; Embong, N.H.; Khazaai, S.N.M.; Rahim, M.H.A.; Yusoff, M.M.; Lee, K.T.; Maniam, G.P. A review for key challenges of the development of biodiesel industry. Energy Convers. Manag. 2019, 185, 508-517. [CrossRef]

3. Guldhe, A.; Singh, B.; Mutanda, T.; Permaul, K.; Bux, F. Advances in synthesis of biodiesel via enzyme catalysis: Novel and sustainable approaches. Renew. Sustain. Energy Rev. 2015, 41, 1447-1464. [CrossRef]

4. Medina, A.R.; González-Moreno, P.; Esteban-Cerdán, L.; Grima, E.M. Biocatalysis: Towards ever greener biodiesel production. Biotechnol. Adv. 2009, 27, 398-408. [CrossRef]

5. Guillén, M.; Benaiges, M.D.; Valero, F. Immobilization and stability of a Rhizopus oryzae lipase expressed in Pichia pastoris: Comparison between native and recombinant variants. Biotechnol. Prog. 2011, 27, 1232-1241. [CrossRef]

6. Lotti, M.; Pleiss, J.; Valero, F.; Ferrer, P. Effects of methanol on lipases: Molecular, kinetic and process issues in the production of biodiesel. Biotechnol. J. 2015, 10, 22-30. [CrossRef]

7. Singh, R.K.; Tiwari, M.K.; Singh, R.; Lee, J.-K. From Protein Engineering to Immobilization: Promising Strategies for the Upgrade of Industrial Enzymes. Int. J. Mol. Sci. 2013, 14, 1232-1277. [CrossRef]

8. Korman, T.P.; Sahachartsiri, B.; Charbonneau, D.M.; Huang, G.L.; Beauregard, M.; Bowie, J.U. Dieselzymes: Development of a stable and methanol tolerant lipase for biodiesel production by directed evolution. Biotechnol. Biofuels 2013, 6, 70. [CrossRef]

9. Wang, Z.; Lv, P.; Luo, W.; Yuan, Z.; He, D. Expression in Pichia pastoris and characterization of Rhizomucor miehei lipases containing a new propeptide region. J. Gen. Appl. Microbiol. 2016, 62, 25-30. [CrossRef]

10. Takahashi, S.; Ueda, M.; Atomi, H.; Beer, H.D.; Bornscheuer, U.T.; Schmid, R.D.; Tanaka, A. Extracellular production of active Rhizopus oryzae lipase by Saccharomyces cerevisiae. J. Ferment. Bioeng. 1998, 86, 164-168. [CrossRef]

11. Satomura, A.; Kuroda, K.; Ueda, M. Generation of a Functionally Distinct Rhizopus oryzae Lipase through Protein Folding Memory. PLoS ONE 2015, 10, e0124545. [CrossRef] [PubMed]

12. Canet, A.; Bonet-Ragel, K.; Benaiges, M.D.; Valero, F. Lipase-catalysed transesterification: Viewpoint of the mechanism and influence of free fatty acids. Biomass Bioenergy 2016, 85, 94-99. [CrossRef]

13. Bonet-Ragel, K.; Canet, A.; Benaiges, M.D.; Valero, F. Synthesis of biodiesel from high FFA alperujo oil catalysed by immobilised lipase. Fuel 2015, 161, 12-17. [CrossRef]

14. Picó, E.A.; López, C.; Cruz-Izquierdo, Á.; Munarriz, M.; Iruretagoyena, F.J.; Serra, J.L.; Llama, M.J. Easy reuse of magnetic cross-linked enzyme aggregates of lipase B from Candida antarctica to obtain biodiesel from Chlorella vulgaris lipids. J. Biosci. Bioeng. 2018, 126, 451-457. [CrossRef]

15. Bonet-Ragel, K.; Canet, A.; Benaiges, M.D.; Valero, F. Effect of acyl-acceptor stepwise addition strategy using alperujo oil as a substrate in enzymatic biodiesel synthesis. J. Chem. Technol. Biotechnol. 2018, 93, 541-547. [CrossRef]

16. Beer, H.; McCarthy, J.E.; Bornscheuer, U.T.; Schmid, R.D. Cloning, expression, characterization and role of the leader sequence of a lipase from Rhizopus oryzae. Biochim. Biophys. Acta BBA Bioenergy 1998, 1399, 173-180. [CrossRef]

17. Sayari, A.; Frikha, F.; Miled, N.; Mtibaa, H.; Ali, Y.B.; Verger, R.; Gargouri, Y. N-terminal peptide of Rhizopus oryzae lipase is important for its catalytic properties. FEBS Lett. 2005, 579, 976-982. [CrossRef]

18. Beer, H.D.; Wohlfahrt, G.; Schmid, R.D.; McCarthy, J.E.G. The folding and activity of the extracellular lipase of Rhizopus oryzae are modulated by a prosequence. Biochem. J. 1996, 319, 351-359. [CrossRef] 
19. Hama, S.; Tamalampudi, S.; Shindo, N.; Numata, T.; Yamaji, H.; Fukuda, H.; Kondo, A. Role of N-terminal 28-amino-acid region of Rhizopus oryzae lipase in directing proteins to secretory pathway of Aspergillus oryzae. Appl. Microbiol. Biotechnol. 2008, 79, 1009-1018. [CrossRef]

20. Hiol, A.; Jonzo, M.D.; Rugani, N.; Druet, D.; Sarda, L.; Comeau, L.C. Purification and characterization of an extracellular lipase from a thermophilic Rhizopus oryzae strain isolated from palm fruit. Enzym. Microb. Technol. 2000, 26, 421-430. [CrossRef]

21. Ben Salah, R.; Mosbah, H.; Fendri, A.; Gargouri, A.; Gargouri, Y.; Mejdoub, H. Biochemical and molecular characterization of a lipase produced by Rhizopus oryzae. FEMS Microbiol. Lett. 2006, 260, 241-248. [CrossRef] [PubMed]

22. López, E.; Deive, F.J.; Longo, M.A.; Sanromán, M.Á.; Braga, M.; Ángeles, S. Lipolytic Enzyme Production by Immobilized Rhizopus oryzae. Chem. Eng. Technol. 2008, 31, 1555-1560. [CrossRef]

23. Hama, S.; Tamalampudi, S.; Fukumizu, T.; Miura, K.; Yamaji, H.; Kondo, A.; Fukuda, H. Lipase localization in Rhizopus oryzae cells immobilized within biomass support particles for use as whole-cell biocatalysts in biodiesel-fuel production. J. Biosci. Bioeng. 2006, 101, 328-333. [CrossRef] [PubMed]

24. Ueda, M.; Takahashi, S.; Washida, M.; Shiraga, S.; Tanaka, A. Expression of Rhizopus oryzae lipase gene in Saccharomyces cerevisiae. J. Mol. Catal. B Enzym. 2002, 17, 113-124. [CrossRef]

25. Takahashi, S.; Ueda, M.; Tanaka, A. Independent production of two molecular forms of a recombinant Rhizopus oryzae lipase by KEX2-engineered strains of Saccharomyces cerevisiae. Appl. Microbiol. Biotechnol. 1999, 52, 534-540. [CrossRef]

26. Takahashi, S.; Ueda, M.; Tanaka, A. Function of the prosequence for in vivo folding and secretion of active Rhizopus oryzae lipase in Saccharomyces cerevisiae. Appl. Microbiol. Biotechnol. 2001, 55, 454-462. [CrossRef]

27. Joerger, R.D.; Haas, M.J. Overexpression of aRhizopus delemar lipase gene inEscherichia coli. Lipids 1993, 28, 81-88. [CrossRef]

28. Di Lorenzo, M.; Hidalgo, A.; Haas, M.; Bornscheuer, U.T. Heterologous Production of Functional Forms of Rhizopus oryzae Lipase in Escherichia coli. Appl. Environ. Microbiol. 2005, 71, 8974-8977. [CrossRef]

29. Minning, S.; Schmidt-Dannert, C.; Schmid, R.D. Functional expression of Rhizopus oryzae lipase in Pichia pastoris: High-level production and some properties. J. Biotechnol. 1998, 66, 147-156. [CrossRef]

30. Potvin, G.; Ahmad, A.; Zhang, Z. Bioprocess engineering aspects of heterologous protein production in Pichia pastoris: A review. Biochem. Eng. J. 2012, 64, 91-105. [CrossRef]

31. Ben Salah, R.; Gargouri, A.; Verger, R.; Gargouri, Y.; Mejdoub, H. Expression in Pichia pastoris X33 of His-tagged lipase from a novel strain of Rhizopus oryzae and its mutant Asn 134 His: Purification and characterization. World J. Microbiol. Biotechnol. 2009, 25, 1375-1384. [CrossRef]

32. Yu, X.W.; Yang, M.; Jiang, C.; Zhang, X.; Xu, Y. N-Glycosylation Engineering to Improve the Constitutive Expression of Rhizopus oryzae Lipase in Komagataella phaffii. J. Agric. Food Chem. 2017, 65, 6009-6015. [CrossRef] [PubMed]

33. Jiao, L.; Zhou, Q.; Su, Z.; Xu, L.; Yan, Y. High-level extracellular production of Rhizopus oryzae lipase in Pichia pastoris via a strategy combining optimization of gene-copy number with co-expression of ERAD-related proteins. Protein Expr. Purif. 2018, 147, 1-12. [CrossRef] [PubMed]

34. Li, X.; He, X.; Li, Z.; Wang, F. Combined Strategies for Improving the Production of Recombinant Rhizopus oryzae Lipase in Pichia pastoris. Bioresour. 2013, 8, 2867-2880. [CrossRef]

35. Canales, C.; Altamirano, C.; Berrios, J. Effect of dilution rate and methanol-glycerol mixed feeding on heterologous Rhizopus oryzae lipase production with Pichia pastoris Mut+ phenotype in continuous culture. Biotechnol. Prog. 2015, 31, 707-714. [CrossRef]

36. Niu, W.N.; Li, Z.P.; Tan, T. Secretion of Pro- and Mature Rhizopus arrhizus Lipases by Pichia pastoris and Properties of the Proteins. Mol. Biotechnol. 2006, 32, 73-82. [CrossRef]

37. Wang, J.R.; Li, Y.Y.; Xu, S.D.; Li, P.; Liu, J.S.; Liu, D.N. High-Level Expression of Pro-Form Lipase from Rhizopus oryzae in Pichia pastoris and Its Purification and Characterization. Int. J. Mol. Sci. 2013, 15, 203-217. [CrossRef]

38. Barrigón, J.M.; Montesinos, J.L.; Valero, F. Searching the best operational strategies for Rhizopus oryzae lipase production in Pichia pastoris Mut+phenotype: Methanol limited or methanol non-limited fed-batch cultures? Biochem. Eng. J. 2013, 75, 47-54. [CrossRef] 
39. Valkonen, M.; Penttilä, M.; Saloheimo, M. Effects of inactivation and constitutive expression of the unfolded-protein response pathway on protein production in the yeast Saccharomyces cerevisiae. Appl. Environ. Microbiol. 2003, 69, 2065-2072. [CrossRef]

40. Guillén, M.; Benaiges, M.D.; Valero, F. Comparison of the biochemical properties of a recombinant lipase extract from Rhizopus oryzae expressed in Pichia pastoris with a native extract. Biochem. Eng. J. 2011, 54, 117-123. [CrossRef]

41. Kohno, M.; Kugimiya, W.; Hashimoto, Y.; Morita, Y. Purification, Characterization, and Crystallization of Two Types of Lipase from Rhizopus niveus. Biosci. Biotechnol. Biochem. 1994, 58, 1007-1012. [CrossRef] [PubMed]

42. Pashangeh, K.; Akhond, M.; Karbalaei-Heidari, H.; Absalan, G. Biochemical characterization and stability assessment of Rhizopus oryzae lipase covalently immobilized on amino-functionalized magnetic nanoparticles. Int. J. Biol. Macromol. 2017, 105, 300-307. [CrossRef] [PubMed]

43. Ben Salah, A.; Sayari, A.; Verger, R.; Gargouri, Y. Kinetic studies of Rhizopus oryzae lipase using monomolecular film technique. Biochimie 2001, 83, 463-469. [CrossRef]

44. Khan, F.I.; Lan, D.; Durrani, R.; Huan, W.; Zhao, Z.; Wang, Y. The Lid Domain in Lipases: Structural and Functional Determinant of Enzymatic Properties. Front. Bioeng. Biotechnol. 2017, 5, 16. [CrossRef] [PubMed]

45. Barrero, J.J.; Casler, J.C.; Valero, F.; Ferrer, P.; Glick, B.S. An improved secretion signal enhances the secretion of model proteins from Pichia pastoris. Microb. Cell Factories 2018, 17, 161-174. [CrossRef]

46. Cámara, E.; Albiol, J.; Ferrer, P. Droplet digital PCR-aided screening and characterization of Pichia pastoris multiple gene copy strains. Biotechnol. Bioeng. 2016, 113, 1542-1551. [CrossRef]

47. Cos, O.; Serrano, A.; Montesinos, J.L.; Ferrer, P.; Cregg, J.M.; Valero, F. Combined effect of the methanol utilization (Mut) phenotype and gene dosage on recombinant protein production in Pichia pastoris fed-batch cultures. J. Biotechnol. 2005, 116, 321-335. [CrossRef]

48. Ponte, X.; Montesinos-Seguí, J.L.; Valero, F. Bioprocess efficiency in Rhizopus oryzae lipase production by Pichia pastoris under the control of PAOX1 is oxygen tension dependent. Process. Biochem. 2016, 51, 1954-1963. [CrossRef]

49. Guillén, M.; Benaiges, M.D.; Valero, F. Biosynthesis of ethyl butyrate by immobilized recombinant Rhizopus oryzae lipase expressed in Pichia pastoris. Biochem. Eng. J. 2012, 65, 1-9. [CrossRef]

50. Diaz, P.; Prim, N.; Pastor, F.J. Direct fluorescence-based lipase activity assay. Biotech. 1999, 27, 696-700. [CrossRef]

51. Cámara, E.; Landes, N.; Albiol, J.; Gasser, B.; Mattanovich, D.; Ferrer, P. Increased dosage of AOX1 promoter-regulated expression cassettes leads to transcription attenuation of the methanol metabolism in Pichia pastoris. Sci. Rep. 2017, 7, 696-700. [CrossRef] [PubMed]

52. Resina, D. Expression of a Rhizopus oryzae lipase in Pichia pastoris under control of the nitrogen source-regulated formaldehyde dehydrogenase promoter. J. Biotechnol. 2004, 109, 103-113. [CrossRef]

53. Bradford, M.M. A rapid and sensitive method for the quantitation of microgram quantities of protein utilizing the principle of protein-dye binding. Anal. Biochem. 1976, 72, 248-254. [CrossRef]

(C) 2019 by the authors. Licensee MDPI, Basel, Switzerland. This article is an open access article distributed under the terms and conditions of the Creative Commons Attribution (CC BY) license (http://creativecommons.org/licenses/by/4.0/). 